\title{
軽度・中等度難聴児の補聴器装用と 言語およびコミュニケーションの指導
}

一新生児聴覚スクリーニング検查導入前出生児一

\author{
井上 理絵1), 大沼 幸恵1), 原 由紀 ${ }^{2)}$ \\ 鈴木 恵子 ${ }^{21}$, 佐野肇 ${ }^{3)}$, 岡本 牧人 ${ }^{3)}$ \\ ${ }^{1)}$ 北里大学病院耳鼻咽喉科 \\ ${ }^{2)}$ 北里大学医療衛生学部 \\ ${ }^{3)}$ 北里大学医学部耳鼻咽喉科
}

\begin{abstract}
要旨 : 新生児聴覚スクリーニング検查の導入後, 出生直後に検出されるようになった軽度 ・中等度難聴児への適切なハビリテーションを検討するため，導入前に出生した症例の実 態を把握する必要があると考えた。対象は平成14 16年度に北里大学病院耳鼻咽喉科で診 断した聴力レベル $70 \mathrm{~dB}$ 未満の軽度・中等度難聴児 30 例で, 初診時評価, 補聴や言語発達, コミュニケーション等に対するハビリテーションに関し診療録をもとに調査した。対象の 平均聴力レベルは $47 \mathrm{~dB}$, 初診年齢は平均 5 歳 9 カ月で, 27 例に言語発達遅滞, 20 例に構 音障害，全例にコミュニケーション上の問題を認めた。ハビリテーションにより15例が補 聴器の終日装用に至った。非装用の要因として家族の理解不足や心理的抵抗，経済的な問 題の関与が示唆された。言語発達の改善には 1 年以上要し, 補聴器の安定装用にも 1 年半 以上要した例があり，長期的，継続的なハビリテーションが必要だった。
\end{abstract}

$$
\text { ーキーワードー }
$$

新生児聴覚スクリーニング検查導入前, 軽度・中等度難聴, 補聴器装用, 言語発達, コミュニケーション

はじめに

一般に，小児の難聴は程度が軽い程検出される時 期が遅く，軽度・中等度難聴では就学前後に診断を 受ける例が多いことが報告されてきだ,2)。しかし平 成12年以降，わが国への新生览聴覚スクリーニング 検查の導入に伴い, 高度難聴ばかりでなく, 軽度 · 中等度難聴も出生直後に検出することが可能にな り, 従来の難聴診断やその後の療育の傾向に変化が もたらされつつある。軽度・中等度難聴では環境音 への反応や喃語が観察され, 語や文の理解・表出も 認められるため，乳幼児期に家族が障害を実感する
ことは難しい3)。新生児聴覚スクリーニング検査の 進展によって, 難聴が言語発達やコミュニケーショ ンに与える影響を明確に捉えにくい乳児期から，補 聴器装用や定期的な通院，療育を促すという新たな 事態が生じることが想定される。このような環境の 変化に応じて今後適切なハビリテーションを行うた めに，新生児聴覚スクリーニング検查導入以前に出 生した軽度・中等度難聴児の実態を, 難聴の検出, 補聴器, 言語発達, 構音, コミュニケーション等の 観点から把握する必要があると考え, これらの症例 の初診時評価およびハビリテーションについて調 查, 検討を行った。 
対

象

平成14 16年度に北里大学病院耳鼻咽喉科で診断 を行い，良聴耳の 3 分法による平均聴力レベルが70 $\mathrm{dB}$ 未満の軽度・中等度難聴児 30 例を対象とした。 初診時の年齢は平均 5 歳 9 力月 \pm 2 歳 1 力月（2 歳 3 力月〜 10 歳 8 力月), 平均聴力レベルは $47 \mathrm{~dB} \pm 13$ $\mathrm{dB}$ である。

\section{方法}

\section{1. 初診時評価}

初診時に, 主訴, 受診の契機, 言語発達, 構音, コミュニケーション行動, 日常の対音反応, 社会参 加の状況を評価した。

言語発達の評価のために，対象の年齢に応じて WPPSI 知能診断検查 (以下 WPPSI), WISC-III 知 能検查法 (以下 WISC-III) ないし ITPA 言語学習能 力診断検査（以下 ITPA）を実施した。4 歳未満の 場合は, 絵カード等を用いて理解・表出語彙（事物 名称や動作語), 大小, 色, 数等の概念形成の有無, 構文の獲得状況等を評価した。

構音の評価には, 日本音声医学会（機能的構音障 害検査法委員会）編集の構音検査を用いた。

聴き返しや聴き誤りといったコミュニケーション 上の問題を, 言語聴覚士が対話場面で観察し評価し た。また, 主訴, 受診の契機, 日常の対音反応や社 会参加については, 家族の記録, 問診から情報を得 た。

\section{2. ハビリテーション}

初診時評価に基づいて, 個々の症例の状態に応じ たハビリテーションプログラムを立案し, 補聴器適 合, 言語や構音, コミュニケーションの指導, 環境 調整等を実施した。その概要は以下のとおりである。

(1) 補聴器適合

補聴器適合では，ハウリングや脱落を防止し安定 した装用を図るために，最初にイヤモールドを作製 した。おおよそ $30 \mathrm{~dB}$ の装用間值が得られるように 補聴器の特性を調整し, 音場での閾值検査を行った 後, まず家庭内での試聴を促した。この際, 家族に 装用状況について記録を依頼し，ほほ 1 週間毎に再 診した。再診時には，家庭記録を評価するとともに 聴性行動の観察や閾值検查を行い, 必要に応じ特性
を再調整した。また，対音反応の観察，装用時間の 延長, 装用場所の拡大等に関して家族指導を行った。 集団場面で装用を開始する際には必ず担任教諭や保 育士と連絡をとり, 補聴器に関する基本的な情報を 伝え, 理解を促し協力を求めた。

(2) 言語発達・構音・コミュニケーションに対す る指導

未就学児に対しては当科で直接指導を行い, 就学 児の場合は補聴器を適合した後, 小学校に併設され たきこえの教室・ことばの教室に指導を引き継い だ。

当科における指導は，基本的に家族同室で個別に 行い, 家族への助言・指導を含め 1 回 1 時間を 1 2 週間隔で実施した。指導場面では, 種々の教材を 用いて直接言語発達を促すとともに, 多様なコミュ ニケーション場面を設定して, 聴取できない状況下 の対応など対象児のコミュニケーションストラテジ 一習得を促した。並行してコミュニケーションパー トナーとしての家族のスキル向上を図り, 助言, 指 導を行った。

(3) 環境調整

家族に対しては，難聴の影響を正しく理解し適切 な養育を行えるように家庭記録の継続を促し，聴性 行動や言語発達への家族の視点を養う助言・指導を 行った。また就学間近の症例に対しては，ことばの 教室やきこえの教室への入級を促した。

教育機関に対しては, 聴力・難聴・補聴器に関す るパンフレットを作成して理解を促した。その上で 文書ないし電話で連絡を取り, 幼稚園・保育園に対 しては補聴器の管理や会話時の配虑, 指示理解の確 認方法等を伝え，実践を要請した。さらに小学校の 学級担任に対しては, 教室での座席決定時の配慮や 重要な情報の板書など視覚情報の活用を依頼し，環 境調整を行った。ことばの教室やきこえの教室に対 しては，当科の指導を報告し引き継ぎを行った。

3. ハビリテーション後の評価

これらのハビリテーションの開始から $3 \sim 6$ カ月 以上経過した後に, 言語発達やコミュニケーション について評価を行い, 初診時の結果と比較した。ま た, 補聴器の装用状況の評価も行った。 
表 1 初診年齢別と平均聴力レベル

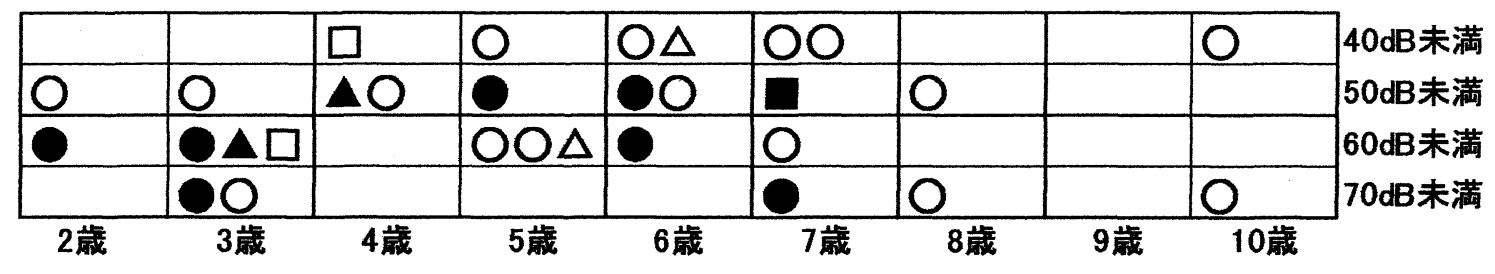

\section{○ 難聴主訴 \\ $\triangle$ 言語発達遅滞主訴 \\ $\square$ 構音障害主訴}

\section{○、 $\Delta, \square$ 受診の契機が家族の心配」 \\ O $\Delta, \square$ 受診の契機が家族の心配以外」}

\section{結果}

\section{1. 初診時評価}

\section{(1) 主訴，受診の契機}

初診時もっとも明らかだった訴え（主訴）は，「難 聴」が23例 $(77 \%)$, 「言語発達遲滞」が 4 例 (13\%), 「構音障害」が 3 例（10\%）であった。受診の契機 は，「家族の心配」が10例 (33\%)，「幼稚園・保育 園・学校の先生の勧め」が 5 例 $(17 \%)$,「他院・療 育施設の紹介」が 5 例 $(17 \%), 「 3$ 歳览健診」が 3 例 $(10 \%)$ ，「学校健診」が 7 例 $(23 \%)$ であった。

表 1 に, 平均聴力レベル（10dB ステップ）と初診 年齢別に，対象の分布を示した。1つの印が 1 例を 表す。平均聴力レベルと初診年齢の間に相関はなか った $(\mathrm{r}=-0.18)$ 。初診年齢 8 歳以上の 4 例全例, および聴力レベル $40 \mathrm{~dB}$ 未満の 8 例全例が「家族の 心配」以外の契機で受診した。初診年齢 8 歳未満な いし聴力レベル40dB 以上の症例の受診の契機には 明らかな傾向を認めなかった。難聴以外の主訴は, $60 \mathrm{~dB}$ 未満の症例にのみ, 受診の契機や聴力に関わ らず散見された。

\section{(2) 言語発達}

4 例にWPPSI， 8 例 に WISC-III，14例に ITPA （WPPSI または WISC-III と併用例あり），および 8 例に絵カード等による言語発達評価を実施した。そ の結果，30例の対象のうち 27 例に言語発達遲滞があ ると判断された。

WPPSI または WISC-IIIを実施した12例の結果を 動作性知能（以下 PIQ）と言語性知能（以下 VIQ） に分けて図 1 に示した。PIQ は全例90以上で視知覚 認知面の発達に遅れはなく, 注意の集中や対人面の 問題もなかった。一方，VIQ が90以上は平均聴力レ

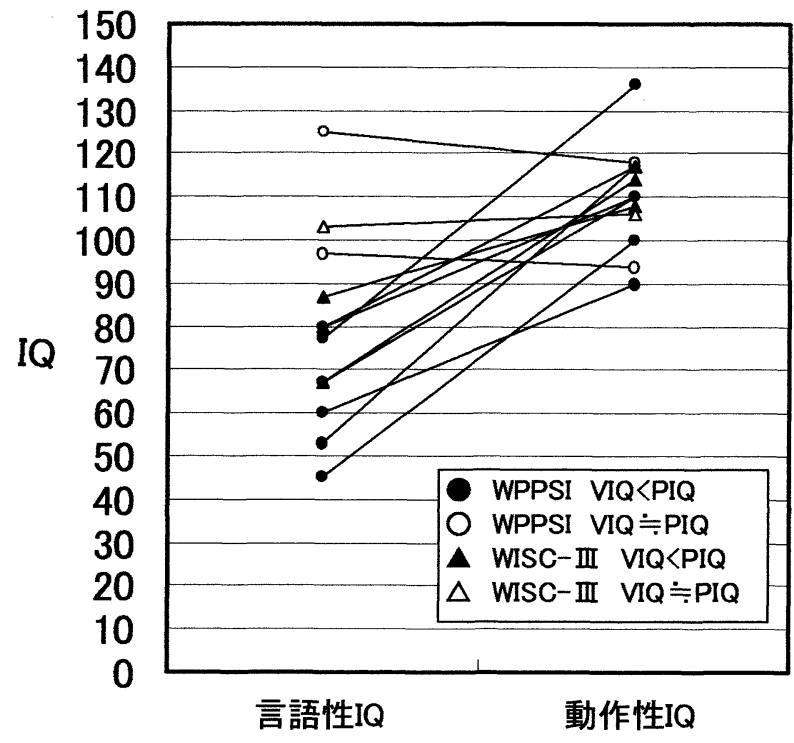

図 1 WPPSI およびWISC-III の言語性 IQ と動作性 IQ

ベル $45 \mathrm{~dB}$ 以下の 3 例のみであった。残る 9 例の VIQ は WPPSI で45〜80，WISC-III で67〜87の範囲を示 し，いずれも PIQ が VIQ より有意 ${ }^{4,5)} に$ 高かった。 言語性検查の下位検查間の評価点にばらつきは認め なかった。

\section{(3) 構音}

構音検查の結果，20例に構音障害を認めた。内訳

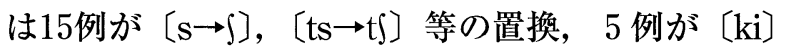
〔t $\mathrm{fi}$ 〔ri]等，イ列音の側音化構音であった。いず れの症例にも発声発語器官の異常は認められなかっ た。

(4) コミュニケーション・対音反応 · 社会参加

言語聴覚士との対話場面で，30例全例に聴き返し や聴き誤りが多い，呼名を無視する，話題の転換が 分からない，一方的に話す等，コミュニケーション 
表 2 難聴を疑うエピソード

\begin{tabular}{|c|c|c|}
\hline & 内容 & 報告数 \\
\hline \multirow[t]{2}{*}{ 環境音への反応 } & $\begin{array}{l}\text { テレビに関するもの } \\
\text { テレビを見ない } \\
\text { テレビの音が大きい } \\
\text { スピーかに耳をあてる } \\
\end{array}$ & 5 \\
\hline & その他の環境音に気つかない & 3 \\
\hline \multirow[t]{5}{*}{ 言語音への反応 } & 㯖き返し-聴き摆りが多い & 14 \\
\hline & 呼名に応答しない時がある & 9 \\
\hline & $\begin{array}{l}\text { 会話時の様子 } \\
\text { 口元をよく見る, 耳を近つける } \\
\text { 話題と無開係なことを一方的に話す } \\
\text { 会話の転換がわからない } \\
\text { 人の話を笑って聴いているのみ }\end{array}$ & 8 \\
\hline & $\begin{array}{l}\text { ことばの発達について } \\
\text { 同胞と比してことばの発達が遅い } \\
\text { 会話からことばを党えない } \\
\text { 何度教えてもことばを賞えない }\end{array}$ & 5 \\
\hline & 歌の歌詞を賞えない，誤って賞える & 3 \\
\hline \multirow[t]{4}{*}{ 社会参加 } & 周りの子を見て行動する & 4 \\
\hline & $\begin{array}{c}\text { 指示がわからない } \\
\text { サッカーコ一チの声が僡こえない } \\
\text { 製作の時間、指示かかかからい }\end{array}$ & 3 \\
\hline & $\begin{array}{c}\text { 消極的な態度 } \\
\text { リトミックの教室に行きたがらない } \\
\text { 合奏に参加しない }\end{array}$ & 2 \\
\hline & 約束を㯖いた-聼かないでトラブルを起こす & 2 \\
\hline
\end{tabular}

上の問題が認められた。

30 例中 26 例の家族から，環境音・言語音への反応 や社会参加に関連した問題を示唆する延べ58件のエ ピソードが報告された。詳細を表 2 に示した。

2. ハビリテーションプログラムの立案

初診時評価の結果, 全例に言語発達遅滞や構音障 害，不適切なコミュニケーション行動が重複して， あるいは単独で認められることが明らかになった。 そこで, 平均 $30 \mathrm{~dB}$ 未満で言語発達が良好な 1 例と 聴力図上複数の鋭いピークを認めた 1 例を除く28例 に，補聴器の適応があると判断した。さらに個々の 問題に応じて, 言語発達の促進, 構音訓練, コミュ ニケーション指導が必要と判断されたため, 全例に 対して個別のプログラムに基づき, 補聴器の適合を 含むハビリテーションを実施するという方針をたて た。

「家族の心配」で受診した例（表 1 の○ロ）が30 例中10例に留まり，しかも，そのうちの 3 例（表 1 のவ口）は言語発達遅滞，構音障害を主訴に受診し ており, 難聴に由来する問題を認識していない家族 が多いことが明らかになった。また，初診時すでに 幼稚園 ·保育園 · 小学校等への集団参加が開始され ている症例が多かったことから，ハビリテーション の初期段階で軽度・中等度難聴について家族や教育 機関の理解を促す働きかけが必要と考え, 環境調整 を重視する方針を立て，指導を開始した。

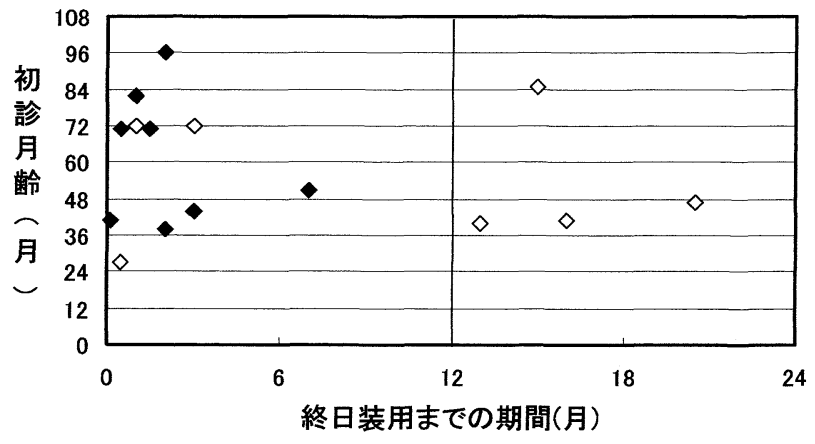

図 2 終日装用までの期間と初診月齢

白い菱形は「家族の心配」が受診の契機であった症例, 黒 い菱形は「家族の心配以外」が受診の契機であった症例。

\section{3．ハビリテーション後の評価}

(1) 補聴器の装用状況

対象を補聴器の装用状況により, 終日継続して装 用する「終日装用」, 集団生活場面あるいは家庭内 等，限られた場面でのみ装用する「場面装用」，補 聴器の適応がなかった, 試聴したが装用に至らなか った，あるいは試聴も行わなかった「非装用」の 3 群に分けると，15例が「終日装用」，9例が「場面 装用」，6 例が「非装用」であった。

「非装用」の内訳は, 補聴器の適応がないと判断 された 2 例（結果 2 で既述）を除くと, 家族が難聴 を否定した 2 例，難聴は否定しないが家族が装用を 拒否した 1 例, 補聴器の試聴はしたが経済的な理由 で購入できなかった 1 例であった。経済的な理由で 非装用となった 1 例は 8 力月間試聴し，学級担任に 促され場面装用も行ったが，購入に至らなかった。 非装用例に対しては，定期的な聴力検査と耳鼻咽喉 科医の診察を促したが，家族が難聴を否定した 2 例 と経済的困難のあった 1 例では受診が途絶えた。

装用状況と初診年齢，受診の契機との関連をみる と，終日装用例の初診が 4 歳 11 力，場面装用例が 6 歳 0 力月, 非装用例が 7 歳 9 力月であり, 終日装 用例が非装用例に比べ初診が有意に早い傾向が認め られた（U=9, p<0.05）。また，受診の契機に関 しては，終日装用例の $47 \% ，$ 場面装用例の $33 \%$ 「゙家 族の心配」だったのに対し，非装用例は全て「学校 健診」や「他院・他施設からの紹介」だった。

終日装用に至った15例について装用が安定するま での期間を調べると， 10 例は 3 力月以内， 4 例は 1 年以上と長短に二分された。初診月歯（図 2), 平 


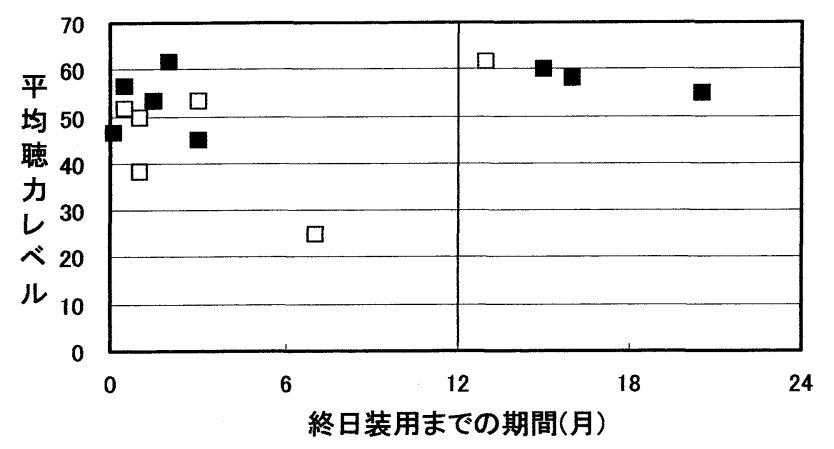

図 3 終日装用までの期間と平均聴力レベル

白い四角は高音障害型の聴力の症例, 黒い四角はそれ以外 の症例

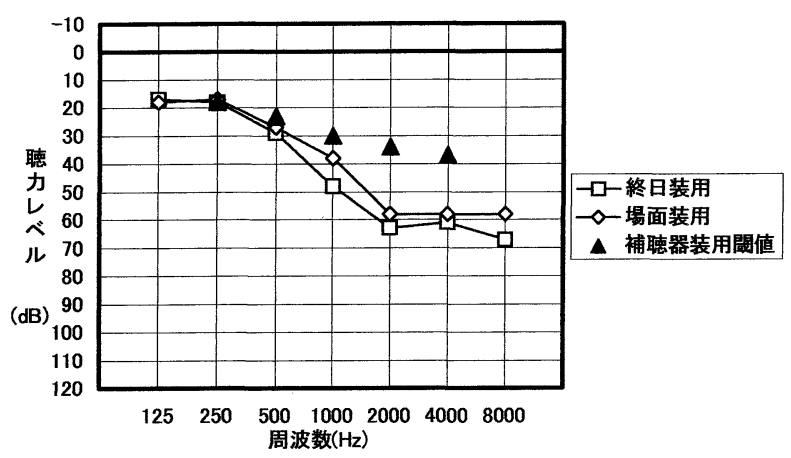

図 4 補聴器装用状況別聴力間值と補聴器装用閾值（高音 障害型）

均聴力レベル（図 3）と終日装用までの期間との間 にはともに明らかな関連を認めず，受診の契機（図 2 ), 聴力型（図 3 ) との関連も明らかではなかっ た。

対象を聴力型により，低音域 $(125 \mathrm{~Hz}, 250 \mathrm{~Hz})$ の聴力閾値が正常範囲の「高音障害型」9 例とそれ 以外に分類すると, 高音障害型の 9 例 (図 4 )では, 6 例が終日装用， 3 例が場面装用となった。装用間 值は $30 \mathrm{~dB} \sim 40 \mathrm{~dB}$ 前後であり，終日装用例と場面装 用例の周波数ごとの聴力レベルの平均に有意差はな かった $(\mathrm{U}=6.5 \sim 12, \mathrm{p}>0.05)$ 。高音障害型以外 の21症例（図 5 ）では 9 例が終日装用，6 例が場面 装用， 6 例が非装用となり，装用間值は $30 \mathrm{~dB}$ 前後 であった。高音障害型以外の 21 症例の平均聴力レベ ルは終日装用例 $55 \mathrm{~dB}$ ，場面装用例 $43 \mathrm{~dB}$ ，非装用例 40 $\mathrm{dB}$ であり，終日装用例が場面装用例より有意に閥 值が高かった（U=6, p<0.05）。また，終日装用 例が非装用例より閾値が高い傾向にあったが，有意 差は認めなかった $(U=10.5, p=0.051)$ 。使用補 聴器は高音障害型 9 例中 7 例がデジタル補聴器, 2

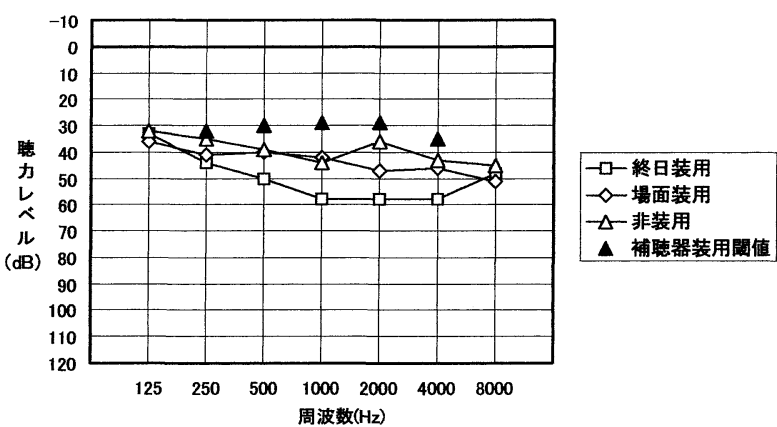

図 5 補聴器装用状況別聴力閾値と補聴器装用閾値（高音 障害型以外)
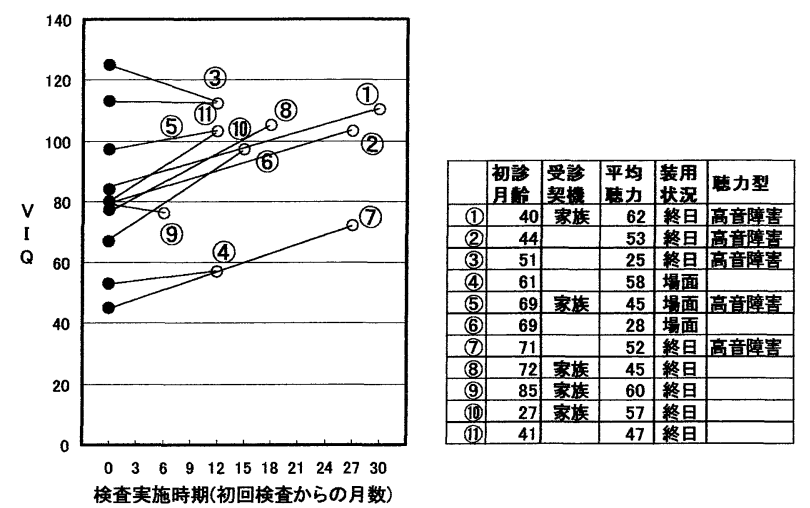

図 6 WPPSI および WISC-III の結果の遷移

例がプログラマブル補聴器であり，それ以外の 21 例 では 8 例がデジタル補聴器， 2 例がプログラマブル 補聴器， 5 例がアナログ補聴器を装用した。

(2) 言語発達・構音

当科またはきこえの教室・ことばの教室で直接的 な指導を行った症例は24例であった。うち 5 例では 構音訓練を実施した。

WPPSI または WISC-III を経時的に行った11例の 初回検查時からの指導期間は 6 カ月〜 30 カ月であっ た。VIQの変化および初診月齢，受診の契機，平均 聴力レベル, 補聴器の装用状況, 聴力型を図 6 に示 した。初回評価時にVIQ が90以上であった症例が 3 例あり，それらを除く 8 例中 6 例の VIQ が15力 月〜27力月の経過中 20 以上有意に改善 ${ }^{4,5)}$ L， 5 例 の VIQ は90以上まで改善した。経過期間 1 年以下 の 2 例では明らかな改善を認めなかった。

(3) コミュニケーション・対音反応・社会参加 補聴器を装用した24例中22例の家庭記録から, 環 境音・言語音に対する反応の変化，ことばの発達， 社会参加の変化について, 延べ32件の報告が得られ 
表 3 補聴器装用状況別聴力閾值と補聴器装用閾値（高音 障害型以外)

\begin{tabular}{|c|c|c|}
\hline & 内容 & 報告数 \\
\hline \multirow{2}{*}{ 環境音に対する変化 } & テレピの音量が小さくなる & 3 \\
\hline & 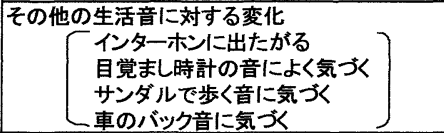 & 10 \\
\hline \multirow[t]{3}{*}{ 言語音に対する変化 } & 聴き返しが減少 & 6 \\
\hline & 普通の声での呼びかけに応答する & 6 \\
\hline & $\begin{array}{l}\text { 会話場面での変化 } \\
{\left[\begin{array}{l}\text { 日常生活から単語を覚える } \\
\text { 新しい誩い回しを使う } \\
\text { 内緒話, 歌が聴きやすい } \\
\text { 質問にそぐわない度答の減少少 }\end{array}\right]}\end{array}$ & 4 \\
\hline \multirow[t]{3}{*}{ 社会参加の変化 } & 置い事のリトミックでよく歌うようになる & 1 \\
\hline & 幼稚園で明るくなり、活動に積極的に参加する & 1 \\
\hline & 劇の練習で先生の指示が分かりやすくなる & 1 \\
\hline
\end{tabular}

た。詳細を表 3 に示した。対音反応や社会参加の変 化は, 補聴器装用後 3 力月以内の早期から観察され た。

\section{考察}

\section{(1) 対象について}

小児の軽度 - 中等度難聴は高度難聴に比べて発見 が痋いことがすでに報告されている。今回の対象の 初診年齢も平均 5 歳 9 力月 \pm 2 歳 1 力月（2 歳 3 力 月〜10歳 8 力月）であり，これまでの報告 ${ }^{1,6,7)}$ とほ ほ同様の時期であった。難聴が幼児期以降に発現す る場合もあり得るが，対象の多くに認められた言語 発達遲滞や構音障害は，これらの症例に先天的ある いは生後間もない時期から難聴が存在したことを推 察させる。また，受診の契機が「家族の心配」の他 に「幼稚園 ·保育園 · 学校の先生の钊め」,「他院 · 療育施設の紹介」,「3 歳児健診」,「学校健診」と多 岐に渡っていること，主訴の傾向が「難聴」だけで はなく「言語発達遅滞」「構音障害」も含まれてい たことも従来の報告 ${ }^{2,8)}$ と類似していた

(2) 補聴器の装用に関与する要因について

補聴器の装用状況を終日, 場面, 非装用の 3 群に 分けて，影響を与えた要因を検討した。聴力レベル に関しては，高音障害型以外では終日装用例が $55 \mathrm{~dB}$ 前後で，場面装用例 ·非装用例の $40 \mathrm{~dB}$ 前後より有 意に高かったが，高音障害型の症例では装用状況に よる平均聴力レベルの差はなかった。またこれま で補聴器適合が難しいとされていた高音障害型9)の 症例が全例終日装用または場面装用となったが，高 音障害型以外の症例と比較してデジタル補聴器を装
用した率が高く，低音域を抑制しながら高音域に十 分な利得が入れられるデジタル補聴器の普及が, こ れらの症例の補聴器装用を促したと推察される。

初診年齢をみると，終日装用例で非装用例より有 意に低かった。初診年齢と聴力レベルに相関はなく， 聴力とは別の要因として初診年齢の遅れが装用状況 に関与する可能性が示唆された。受診の契機をみる と，終日装用例の $47 \%$ ，場面装用例の $33 \%$ 「家族 の心配」であったのに対し，非装用例は全て「学校 健診」や「他院・他施設からの紹介」であった。こ の結果は，難聴に由来する問題に気づいていなかっ た家族が，指導を受けても補聴器の有用性を十分に は理解できず，装用を受け入れにくかったことを推 察させる。さらに今回の対象は全例平均聴力レベル $70 \mathrm{~dB}$ 未満であったため身体障害者手帳交付の対象 外であり，補聴器を試聴し，その有効性を家族，本 人ともに理解したにもかかわらず，購入を断念した 例も認められた。これらの結果は補聴器の装用状況 に聴力だけでなく，初診年歯，難聴に対する家族の 理解や心理的抵抗, 経済的な問題等が関与し得るこ とを示唆しており，これまでも同様の傾向が報告さ れている ${ }^{7,10)}$ 。家族の理解を促すためにはハビリテ ーション担当者のきめ細かな対応が，経済的問題に 対しては行政上の援助について善処が望まれるとこ ろである。

(3) 補聴器の終日装用について

補聴器を終日装用できた症例について，終日装用 が可能になるまでの期間は，試聴開始から 3 力月以 内の早期に装用が安定した例と 1 年以上の長期を要 した例に二分された。早期安定例と長期を要した例 との間で, 聴力レベルや初診年齢, 聴力型, 受診の 契機等に明らかな差はなく，装用安定までにかかる 時間には個人差が大きいと考えられた。さらに，家 族の認識の違い, 教育機関の対応や協力の程度, 本 人が難聴による困難を認識する場面の多寡などの要 因についても検討が必要であろう。

(4) ハビリテーションについて

言語発達遅滞, 構音障害, コミュニケーション上 の問題等，難聴が要因と推定される問題を生じてい る症例が高率に存在した。しかし，受診の契機や主 訴の実態は, 家庭生活の中で家族が軽度 · 中等度難 聴に起因する問題点 ${ }^{11)}$ を認識することの難しさを強 
く示唆するものであった。そのため, 補聴器適合, 言語指導, 構音訓練等のハビリテーションを行って いく初期の段階で，家族にこれらの問題の要因が難 聴であることの認識を促す環境調整が必要と考えら れた。ハビリテーションの経過中, 補聴器適合後 3 カ月以内に環境音や言語音への反応の改善が報告さ れた。これらは補聴器によって適切な閾值が得られ たことを直接反映した結果と考えられるが，この時 期に日常の対音反応を観察し記録することを通じ て,家族の難聴への認識も深められたと推測される。 さらに, コミュニケーション行動, 社会参加におけ る変化も補聴器適合後 3 力月以内と, 比較的早期に 報告されたが，これらには補聴による䦨値の改善と ともに，本人に対するコミュニケーションストラテ ジーの促進，家族や教育機関に対する環境調整も寄 与したと推測される。これら補聴後早期に生じた変 化に対して, 言語発達上の変化は, 多くの症例で 1 年以上の定期的な個別言語指導を経過してから顕れ ており， 1 年未満の指導例では明らかでなかった。 この結果は, 補聴により良好な閾值が得られても， 言語面の障害を軽減するためには，状態に合わせた 個別的で直接的な介入を長期にわたって害施するこ とが, 軽度・中等度難聴においても重要であること を示唆する。

適切な補聴による閾值の改善, 軽度・中等度難聴 の特性の理解促進を柱とした環境調整, そして, 個々 の症例の状態に応じた言語, 構音, コミュニケーシ ヨンに対する指導・訓練が，幼児期以降に診断され た軽度・中等度難聴児のハビリテーションの基本的 な構成であることが, 今回の分析から明らかになっ たといえる。

\section{(5) 今後の展望}

新生児聴覚スクリーニング検查の導入に伴い，軽 度・中等度難聴が早期に発見され 1 歳代から補聴器 の装用を開始する軽度・中等度難聴児が増加してい る。今回の検討から, 軽度・中等度難聴児でも適切 な指導・支援がないまま成長すると，言語発達の遅 れ, 構音障害, コミュニケーション上の問題等が引 き起こされることが明らかになった。この結果を踏 まえると, 新生览聴覚スクリーニング検査によって 早期に検出された軽度・中等度難聴児のハビリテー ションにおいても，障害に対する家族の理解促進,
補聴器の適合, 定期的な言語発達の評価と個々の状 態に応じた指導などを考慮すべきと考えられる。こ れらの介入を従来より数年早く乳児期から行うこと によって，言語発達や構音，コミュニケーションへ の難聴の影響がどの程度軽減されるのか, また，就 園前から軽度・中等度難聴に関する周囲の理解を促 すことで積極的な集団参加が可能となるのか等を， 今後検討していきたいと考える。

$$
\text { まと め }
$$

新生児聴覚スクリーニング検査導入前の軽度・中 等度難聴児30例の初診時評価とハビリテーションに ついて検討した。

1. 初診年齢は 5 歳 9 カ月, 平均聴力レベルは 47 $\mathrm{dB}$ であり, 全例にコミュニケーションの問題が, 27 例に言語発達遅滞，20例に構音障害が認められた。

2. 補聴器は 15 例が終日装用, 9 例が場面装用, 6 例が非装用であった。装用状況に聴力レベルと聴 力型のほか, 初診年齢, 受診の契機, 本人·家族の 難聴の自覚, 経済的困難等, 複数の要因が関与する ことが示唆された。

3 . 補聴後 3 力月以内に, 環境音や語音への反応, コミュニケーション, 社会参加の様子に変化が顕れ た。一方, 言語力の改善はハビリテーションが 1 年 以上経過してから検查結果に顕れた。

4. 軽度・中等度難聴児にとって, 適切な補聴, 難聴理解を促す環境調整，および状態に応じた言語 指導等を含む個別的で長期的なハビリテーションが 重要と考える。

\section{A follow-up study on hearing, speech and aural communications for children with mild-to-moderate hearing loss}

Rie Inoue ${ }^{1)}$, Sachie Onuma ${ }^{1)}$, Yuki Hara ${ }^{2)}$, Keiko Suzuki $^{2)}$, Hajime Sano ${ }^{3)}$, and Makito Okamoto ${ }^{3)}$ ${ }^{1)}$ Department of Otolaryngology, Kitasato University Hospital

${ }^{2)}$ School of Allied Health Science, Kitasato University

${ }^{3)}$ Department of Otolaryngology, Kitasato University School of Medicine 
In this report, the result of our follow-up study of those children with mild-to-moderate hearing loss who were born before the introduction of Newborn Hearing Screening is presented. The subjects were 30 children diagnosed at Kitasato University Hospital as having hearing loss less than $70 \mathrm{dBHL}$, during the period from 2002 to 2004 . The average age at their first visit to the hospital was 69 months, and the average hearing threshold level was $47 \mathrm{~dB}$. All the subjects were found to have communication problems. Delayed language development was noted in 27, while articulation disorders were found in 20. Following our habilitative intervention, 15 subjects adopted hearing aids all day long. Within several months of habilitation, active social commitment was observed. A year later, an improvement in language development was noted. Most of the parents had some difficulty in understanding the possible problems caused by hearing loss. The apparent lack of universal use of hearing aids seemed to be due partly to the ignorance of the parents or to their economical situation. It was stressed that developing an effective program must be put in place to promote the parents' recognition of various problems surrounding children with mild-to-moderate hearing loss.

\section{参考文献}

1 ）杉内智子, 佐藤紀代子, 浅野公子, 他：軽度 · 中等度難聴児 30 症例の言語発達とその問題。日耳 鼻 $104: 1126-1134,2001$

2 ）遠藤重典: 軽・中等度難聴児における障害発見 と診断をめぐる諸問題。聴覚言語障害 $28(3): 163$ $-173,1999$
3 ) Antonia B, Diane B:The Hearing Impaired Child : Infancy Through High-School Year. Andover Medical Publishers : 153-159, 1992

4 ) 小田信夫, 茂木茂八, 安富利光: WPPSI 知能 診断検查手引き。日本文化科学社：18-27, 1996

5 ) 東洋, 上野一彦, 藤田和弘：日本版 WISC -III 知能検查法。日本文化科学社 : 37-75, 1999

6 ）林 初美, 工藤典代, 笹村佳美: 軽度および中 等度難聴児の言語発達について。 小児耳 Vol. 18, No. $2: 53-58,1997$

7 ）久我裕子, 杉井亜也子, 川島貴之：中等度難聴 児における補聴器の装用効果と問題点について。 小児耳 Vol. 18，No2：59-62, 1997

8 ) 塚田晴代, 長井今日子, 小原沢昌子: 学齢期の 軽度, 軽中等度感音性難聴児における補聴器適合 の検討。Audiology Japan 41：214-220, 1998

9 ) 武田 篤: 補聴器装用が困難な軽度・中等度難 聴児の検討。聴覚言語障害 33 巻 1 号 : 1-6, 2004

10）杉内智子, 浅野公子, 新井景子, 他: 軽度-中 等度難聴児の補聴器装用経過の検討一特に装用困 難例について一。肾耳 Vol21, No. 1 ：54-58, 2000

11) Raymond $H$ : Aural Rehabilitation. Singular Publishing Group, Inc. : 25-27, 1997

（原稿受付 平成19.4.23）

別冊請求先 $=228-8555$ 神奈川県相模原市北里115-1

北里大学病院耳鼻咽喉科

井上 理絵

\section{Reprint request :}

Rie Inoue Department of Otolaryngology, Kitasato University Hospital, 1-15-1 Kitasato Sagamihara city, Kanagawa 228-8555, Japan 